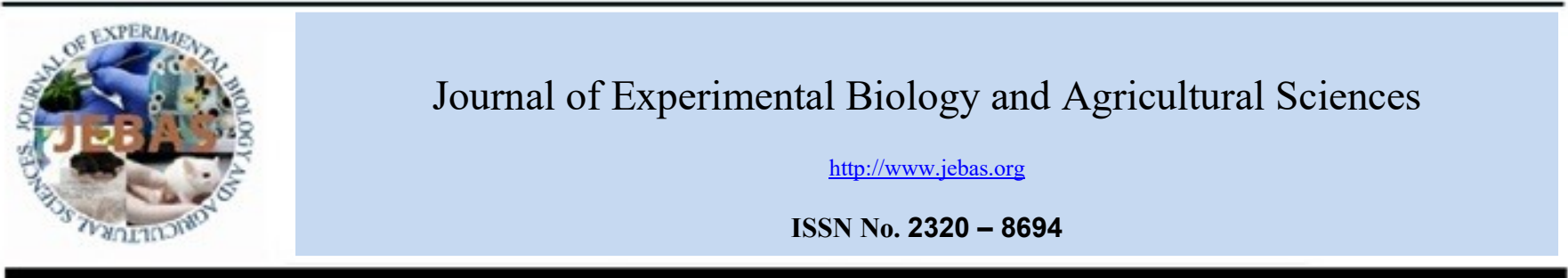

\title{
EFFECT OF CRUDE OIL POLLUTION ON SOIL AND AQUATIC BACTERIA AND FUNGI
}

\section{Eze Chibuzor Nwadibe*, Eze Emmanuel Aniebonam, Okobo Uchenna Jude}

Department of Microbiology, University of Nigeria, Nsukka

Received - February 25, 2020; Revision - March 31, 2020; Accepted - April 14, 2020

Available Online - April 25, 2020

DOI: http://dx.doi.org/10.18006/2020.8(2).176.184

KEYWORDS
Crude oil
Pollution
Ecosystem
Microorganisms
Soil
Water

\begin{abstract}
Crude oil and its derivatives are among the most potent contaminants of the environment, affecting both the biotic and abiotic components of the ecosystem. The present study was undertaken to evaluate the effects of crude oil contamination on terrestrial and aquatic microorganisms. Eight different concentrations of crude oil (Bonny light) were used to contaminate soil and water samples obtained from pristine environments. Both the control and polluted samples were organized in triplicates and the studies carried out by plate count procedures using nutrient agar and sabouraud dextrose agar for bacteria and fungi respectively. Effect of the crude oil on bacterial and fungal counts was significantly $(\mathrm{P}<0.05)$ inhibitory and dose-dependent with $15.0 \%$ and $20.0 \%$ levels of pollution having the highest impact on the microbial counts. In the control soil samples, bacterial numbers varied between $2.32 \times 10^{9}$ to $2.80 \times 10^{9} \mathrm{cfu} / \mathrm{g}$ while their numbers varied between $2.00 \times 10^{8}$ to $2.77 \times 10^{9} \mathrm{cfu} / \mathrm{g}$ in the test samples. For the fungi, numbers varied from $1.02 \times 10^{7}$ to $1.39 \times 10^{7} \mathrm{cfu} / \mathrm{g}$ in the control soil while it was reported $1.60 \times 10^{5}$ to $1.18 \times 10^{7} \mathrm{cfu} / \mathrm{g}$ for the test samples. Results showed that both bacteria and fungi were significantly affected by crude oil contamination, among tested microorganisms marine microorganisms demonstrated some tolerance against crude oil contamination.
\end{abstract}

* Corresponding author

E-mail: chibuzor.eze@unn.edu.ng (Eze Chibuzor Nwadibe)

Peer review under responsibility of Journal of Experimental Biology and Agricultural Sciences.

Production and Hosting by Horizon Publisher India [HPI] (http://www.horizonpublisherindia.in/).

All rights reserved.
All the articles published by Journal of Experimental Biology and Agricultural Sciences are licensed under a Creative Commons Attribution-NonCommercial 4.0 International License Based on a work at www.jebas.org.

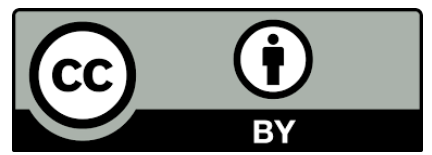




\section{Introduction}

Since the discovery of petroleum as an energy source it has remained the mainstay of many national economies. In spite of this crude oil and its products have been shown to be toxic to living organisms as well as arable lands (Eze et al. 2013; Xue et al., 2015; Wang et al., 2018; Abdullah \& Peramaiyan, 2019). Oil spill incidents in Nigeria are major environmental issues especially in the oil-producing Niger Delta region. Nigeria has had over 4000 oil spills ranging from minor spills of a few hundred barrels to over half a million barrels in a single incident. Releases of petroleum into the environment occur naturally from seeps as well as from human sources. These spillages have caused much destruction of flora, fauna and arable lands in Nigerian environment (Ekpo \& Udofia, 2008). On the whole, natural and human sources introduce about 380 million gallons of oil into the marine environment annually (National Research Council, 2002). About 55\% from this arises from human sources via petroleum production and transportation while the remainder comes from natural seeps.

Present day technology is inadequate to handle such large spills. However, techniques employed include mechanical containment with booms and removal using suction equipment and sorbents, chemical treatment with detergents, and physical removal (National Oceanic and Atmospheric Administration, 1992). Natural processes account for the removal of a large percentage of petroleum spills from the environment. Natural removal of petroleum from water takes place through evaporation, photooxidation, microbial degradation and utilization (Yan et al., 2018; Xingjian et al., 2018; Xinxin et al., 2019). Some microorganisms involved in crude oil degradation, detoxication and bioremediation of polluted environments. Notwithstanding, petroleum hydrocarbons have been shown to have deleterious effects on microorganisms through reduction of cell membrane permeability due to its hydrophobicity leading to reduced water and nutrient absorption (Pezeshki et al., 2000) as well as oxygen exchange between soil and the atmosphere (Adedokun \& Ataga, 2007). Even though general reports abound on the negative effects of crude oil on living organisms and arable land, there is paucity of research work on its effects on microorganisms specifically. This research work was undertaken to evaluate the relative impact of crude oil on bacterial and fungal populations by checking its effects on their numbers, soil microbial respiration and phospholipids content.

\section{Materials and Methods}

Bonny light crude oil, uncontaminated sandy loam soil, marine and freshwater samples are the materials which were used in current study. The crude oil was supplied by the Nigerian National Petroleum Corporation (NNPC), Port Harcourt, Rivers State,
Nigeria. Sandy loam soil was obtained from Botany Garden, University of Nigeria.

\subsection{Evaluation of the Impact of Crude Oil on Microbial Numbers in Soil}

Non-petroleum contaminated sandy loam soil was air dried, sieved and measured in $0.5 \mathrm{~kg}$ portions into twenty-seven plastic buckets $(13 \mathrm{~cm} \times 12 \mathrm{~cm})$. The buckets were arranged in triplicates and each triplicate set apart from the control was contaminated with one of the following concentrations of crude oil i.e. $0.5 \%, 1.0 \%, 2.0 \%$, $2.5 \%, 5.0 \%, 10.0 \%, 15.0 \%$ or $20.0 \% \mathrm{v} / \mathrm{w}$. After crude oil addition the soil in each bucket was thoroughly mixed. Microbiological assay was done with $1.0 \mathrm{~g}$ of soil from each bucket every week for eight weeks. The population of viable microbial cells (bacteria and fungi) in each soil sample was determined by the spread plating technique as described by Wistreich (1997) using nutrient agar and sabouraud dextrose agar for bacterial and fungal cultivations respectively.

\subsection{Evaluation of the Impact of Crude Oil on Microbial Numbers in Water}

Marine and freshwater samples were each measured in $200 \mathrm{ml}$ volumes into twenty-seven $500 \mathrm{ml}$ flasks grouped in triplicates. Each triplicate set excluding the controls was contaminated with one of the following concentrations of crude oil viz., $0.5 \%, 1.0 \%$, $2.0 \%, 2.5 \%, 5.0 \%, 10.0 \%, 15.0 \%$ or $20.0 \% \mathrm{v} / \mathrm{v}$. Uncontaminated marine and fresh water were used as control samples. Microbiological assay was carried out with $1.0 \mathrm{ml}$ of water from each flask every week for eight weeks. The spread plating technique was also used for the determination of microbial numbers and the media were nutrient agar and sabouraud dextrose agar for bacteria and fungi respectively.

\subsection{Determination of the Effects of Crude Oil on Soil Microbial Respiration}

This was carried out by the method of Isermeyer (1952) which quantified the level of carbon di oxide $\left(\mathrm{CO}_{2}\right)$ evolved from the soil microbes. Fifty grams of each soil sample was weighed in duplicate into beakers placed inside jars with air-tight covers. A 25 $\mathrm{ml}$ volume of $0.05 \mathrm{M} \mathrm{NaOH}$ was introduced into each jar and the jars were instantly sealed with rubber rings. Controls for both contaminated and uncontaminated soil samples consisted of three jars, each containing $0.05 \mathrm{M} \mathrm{NaOH}$ without soil. All jars were incubated at $25^{\circ} \mathrm{C}$ for 3 days.

Following incubation, the beakers were brought out and their external surfaces washed with $\mathrm{CO}_{2}$-free water. Subsequently, $5 \mathrm{ml}$ of $0.5 \mathrm{M}$ barium chloride solution was introduced into each jar and few drops of phenolphthalein indicator were also added. This was followed by the addition of few drops of hydrochloric 
acid $(0.05 \mathrm{M})$ with continuous stirring until the colour changed from red to colourless. The rate of microbial respiration in soil was calculated with the following formula devised by Isermeyer (1952):

$$
\mathrm{CO}_{2}(\mathrm{mg}) / \mathrm{SW} / \mathrm{t}=\frac{(\mathrm{Vo}-\mathrm{V}) \times 1.1}{\mathrm{DWT}}
$$

Where SW is the amount of soil dry weight in grams, $\mathrm{T}$ is the incubation time in hours, $\mathrm{Vo}$ is the volume of $\mathrm{HCl}$ used for blank titration (average value) in milliliters. $\mathrm{V}$ is the volume of $\mathrm{HCl}$ used for the soil sample (average value), DWT is the dry weight of $1 \mathrm{~g}$ moist soil and 1.1 is the conversion factor $(1 \mathrm{ml} 0.05 \mathrm{M} \mathrm{NaOH}$ equals $1.1 \mathrm{mg} \mathrm{CO}$ ).

\subsection{Determination of Microbial Phospholipid Phosphate (PLP)}

This was done by the method of Frostegard et al. (1991) with some modification. Glass containers used for estimation of PLP were washed with methanol and $15 \% \mathrm{HNO}_{3}$; this was followed by the rinsing twice with tap water and thrice with deionized water. Phospholipids were extracted using a chloroform : methanol : citrate buffer solvent in a ratio of $1: 2: 0.8 \mathrm{v} / \mathrm{v} / \mathrm{v}$. The citrate buffer was made up of $0.015 \mathrm{M}$ citric acid and $0.15 \mathrm{M}$ trisodium citrate at a ratio of $5.9: 4.1 \mathrm{v} / \mathrm{v}$ to give a $\mathrm{pH}$ of 4.0 . A $1.0 \mathrm{~g}$ wet weight of soil was put in a Mc Cartney bottle containing $11.65 \mathrm{ml}$ of the extraction solvent. The ratio of chloroform to soil was $3: 1$ as prescribed by Frostegard et al. (1991). Two hours later, $3.1 \mathrm{ml}$ of citrate buffer and $3.1 \mathrm{ml}$ of chloroform were added with intermittent shaking for another hour to enhance extraction. The solutions were left overnight to dissociate into two partitions. A $6.4 \mathrm{ml}$ volume of the lower chloroform partition was removed using a syringe and put into a vial, taking care not to include any soil particles. An aliquot $(0.1-1.0 \mathrm{ml})$ was transferred to a $5 \mathrm{ml}$ bijou bottle and dried with nitrogen.

Digestion and phospholipid assay were carried out using the method of Findlay et al. (1989). Lipid extracts and glycerol phosphate standards were treated with $1.8 \mathrm{ml}$ of acidified potassium persulphate $\left(\mathrm{K}_{2} \mathrm{~S}_{3} \mathrm{O}_{8}\right)$ solution (5g to $100 \mathrm{ml}$ of $\left.0.35 \mathrm{~N} \mathrm{H}_{2} \mathrm{~S}_{4}\right)$ for $24 \mathrm{~h}$ at $95^{\circ} \mathrm{C}$. The mixture was still hot, this was followed by the addition of $0.4 \mathrm{ml}$ of ammonium molybdate solution and allowed to stay for $10 \mathrm{~min}$ before the introduction of $1.8 \mathrm{ml}$ of malachite green solution. Optical absorbance at $610 \mathrm{~nm}$ was read after $30 \mathrm{~min}$. Distilled water was used for the zero.

\subsection{Statistical analysis}

Data analysis was carried out using a two-way analysis of variance (ANOVA) and the difference done by comparing tests with $\mathrm{P}<0.05$.

\section{Results}

\subsection{Effects of Crude Oil on the Colony Counts of Soil and Aquatic Bacteria and Fungi}

Effects of different crude oil concentrations on microbial numbers in soil and water are presented in Figures 1 and 2. The pristine soil

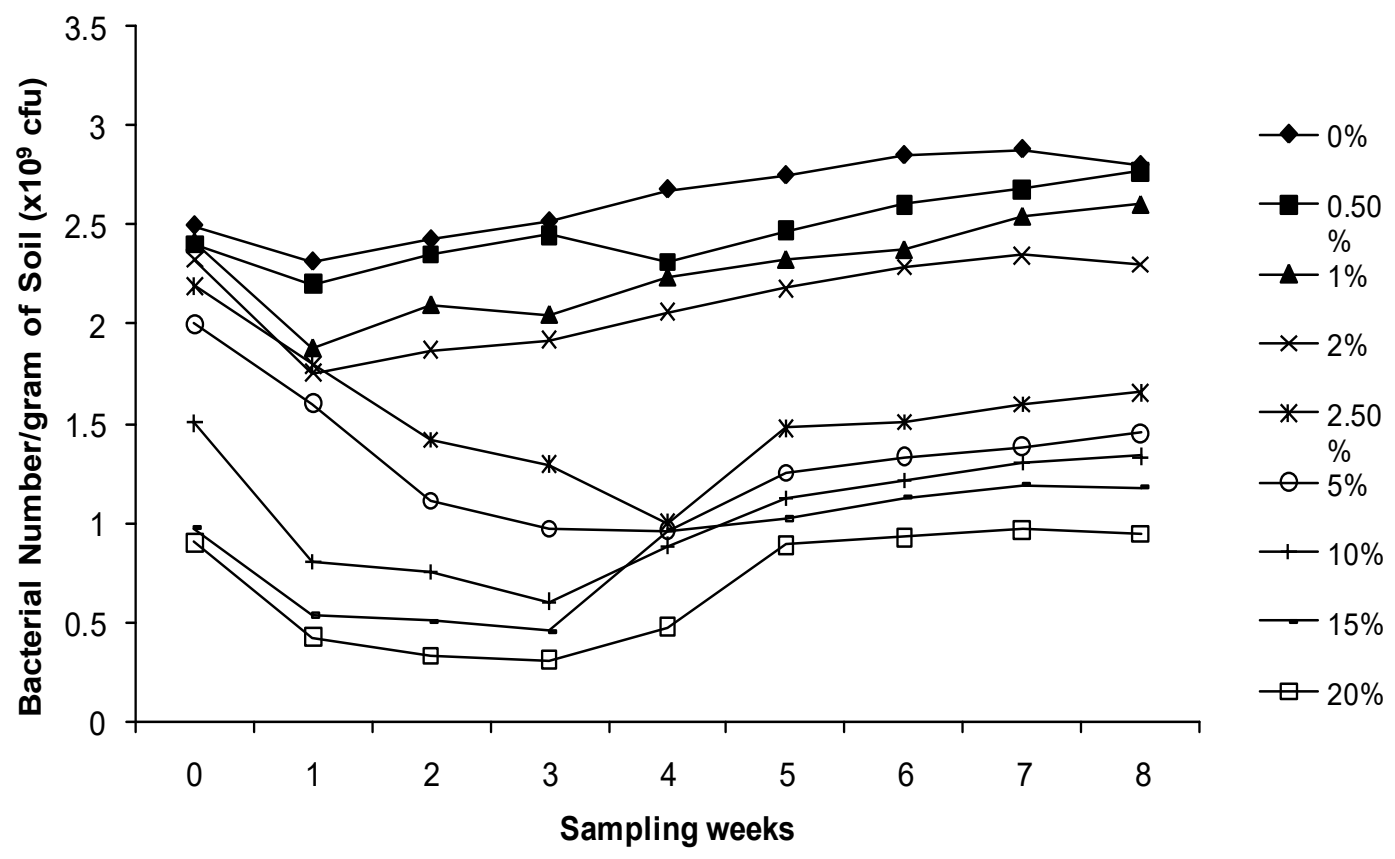

Figure 1 Effects of varying levels of crude oil on total colony count of soil bacteria 


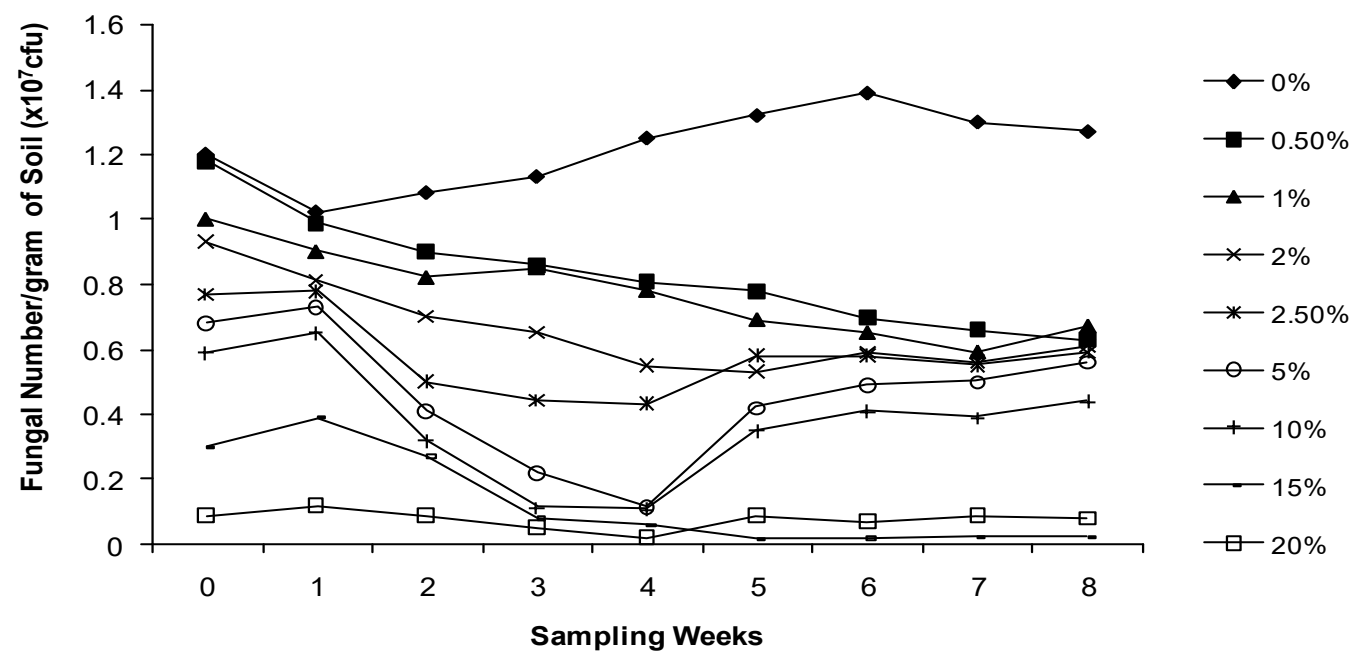

Figure 2 Effects of varying levels of crude oil on total colony count of soil fungi

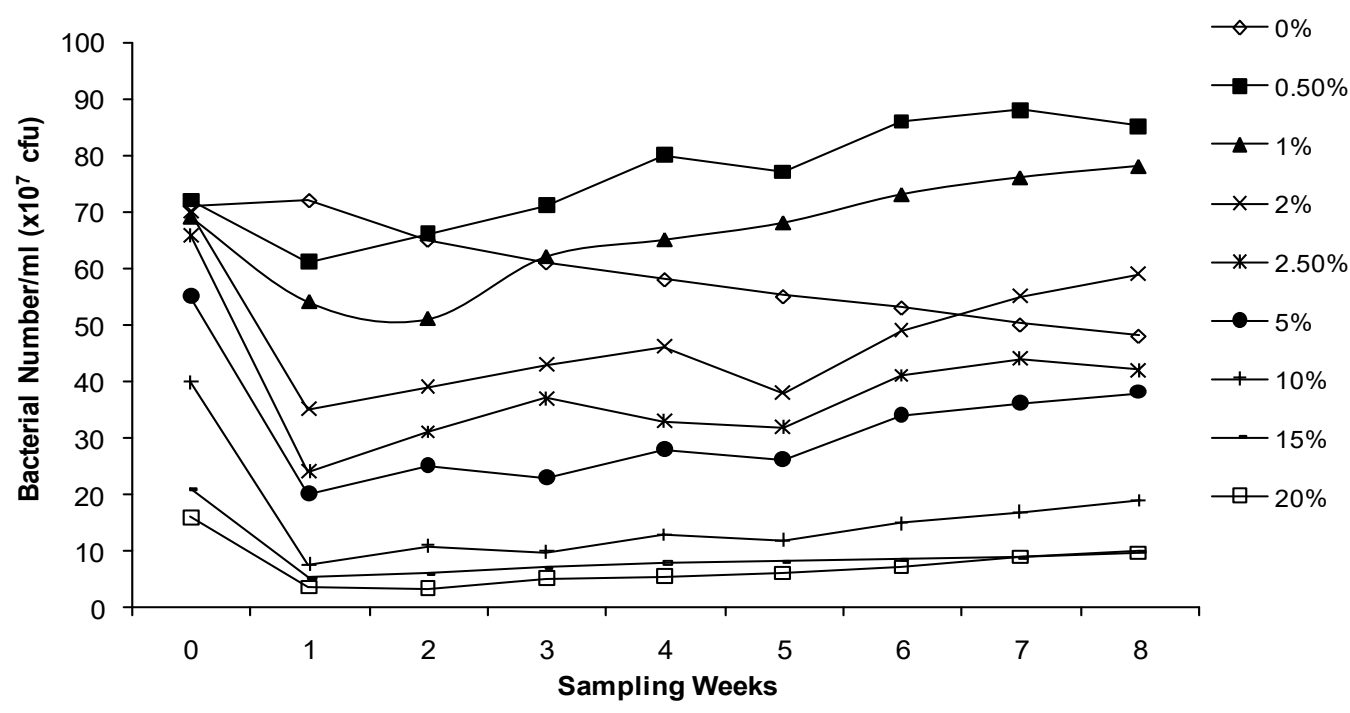

Figure 3 Effects of crude oil on the total colony count of marine bacteria

sample ( $0 \%$ pollution) experienced increase in bacterial numbers from the first week to the eight week. At low concentrations (0.5-2\%) the crude oil did not have significant negative effects on the cell number of the soil bacteria. The growth curves (Figure 1) at lower concentrations (0.5-2\%) was slower for first week, after which they increased progressively till the eighth week. So, when it compared to the control $(0 \%)$, there is no significant difference between them. On the contrary, crude oil at high levels $(2.5 \%-20 \% \mathrm{v} / \mathrm{w})$ had a significant $(\mathrm{P}<0.05)$ negative effect on bacterial cell numbers. There was a sharp reduction in bacterial populations at $2.5 \%$ crude oil level from the first week to the fourth week. Afterwards a gradual increase in population was noted from the fifth week to eighth week.
The fungi seemed to be more prone to the toxic effects of crude oil. This is evidenced by the progressive decrease in fungal numbers with time at the different concentrations of crude oil (Figure 2). Maximum inhibition in fungal growth was reported at 15 and $20 \%$ (v/w) concentration of crude oil.

Figures 3 and 4 showed the effects of crude oil on the cell numbers of marine and freshwater bacteria. Like soil bacteria, reduction in the cell numbers of these bacteria was reported at the first week, this was followed by the gradual increase in bacterial numbers with the exposure time increased (Figure 3 \& 4). Freshwater bacteria were more susceptible to crude oil toxicity than their marine 
counterparts as evidenced by the higher population recorded in marine than freshwater bacteria. Contrary to the bacteria, exposure time of the fungi to crude oil did not enhance their population (Figures 5 and 6 ). The same trend also occurred in the fungi (Figure 5,6). In all the aquatic bacteria and fungi the toxic effects of crude oil were highest at $15 \%$ and $20 \%$ pollution levels.

\subsection{Impact of Crude Oil on Microbial Respiration and Phospholipid Phosphate (PLP)}

Results of these analyses are shown in Figures 7 to 9. Microbial respiration was evaluated from the quantity of Carbon di oxide emitted from the soil over a specific period. According to the results, high concentrations of crude oil (15\% and $20 \%)$ significantly $(\mathrm{P}<0.05) \quad$ decreased $\quad \mathrm{CO}_{2}$ emission (Figure 7) as well as phospholipid phosphate in the soil samples. The length of time microorganisms were exposed to the crude oil (especially low to moderate levels) increased the levels of $\mathrm{CO}_{2}$ and PLP in the soil (Figure 7 and 8). Mean maximum levels of $\mathrm{CO}_{2}$ and PLP in the test samples occurred at $0.5 \%$ and $1.0 \%$ crude oil contaminations. This trend was also observed with the PLP and maximum levels also occurred at $0.5 \%$ and $1.0 \%$ crude oil pollution levels. There was a positive correlation (Pearson's Correlation Model) between soil $\mathrm{CO}_{2}$ and PLP (correlation coefficient $=0.74)$.

\section{Discussion}

Result of current study clearly indicated that crude oil contamination negatively affected the microbial population, in this manner results of current study are in agreement with the findings of previous researchers (Boethling \& Alexander, 1979; Long et al., 1995), this is only manifest at high oil concentrations (Ma et al., 2015). Results of this study show low levels of crude oil (0.5-2.0\%) did not have any negative effect on microbial population. This might be because at low levels hydrocarbonoclastic microorganisms very easily metabolize crude oil as carbon source for their growth (Adedokun \& Ataga, 2007).

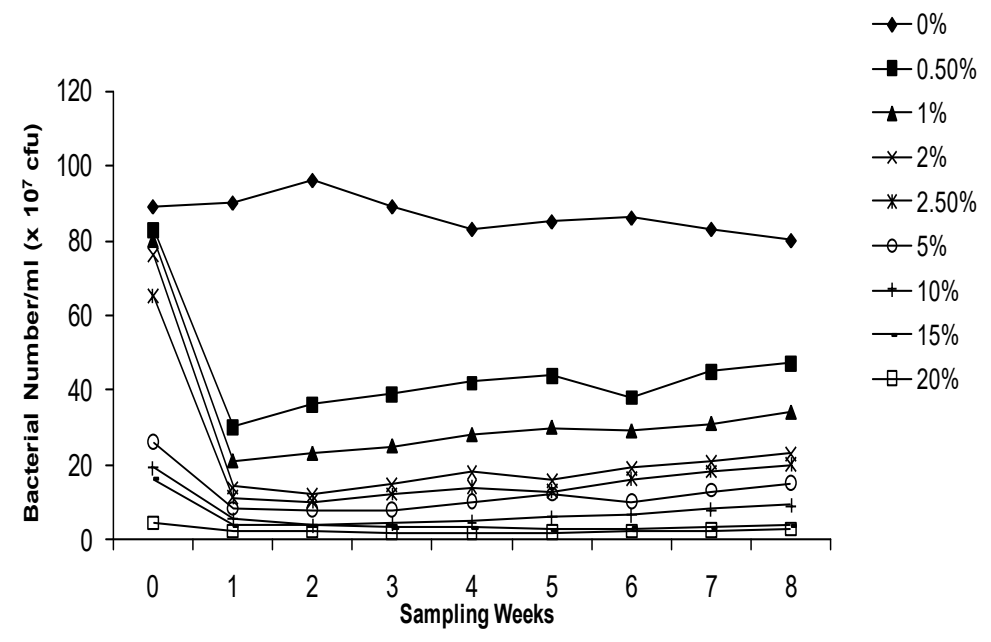

Figure 4 Effects of crude oil on the total colony count of fresh water bacteria

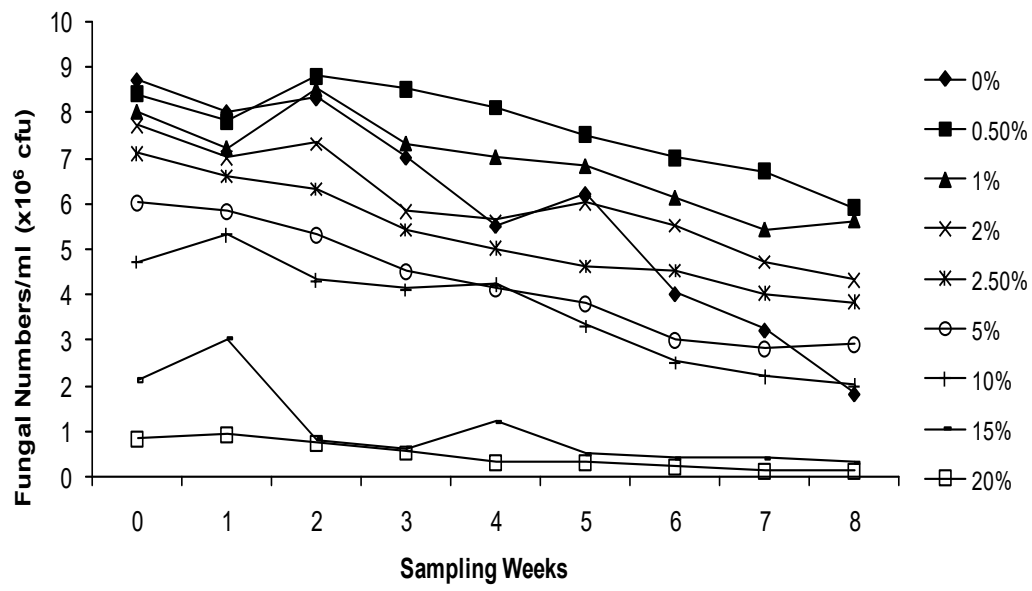

Figure 5 Effects of crude oil on the total colony count of marine fungi

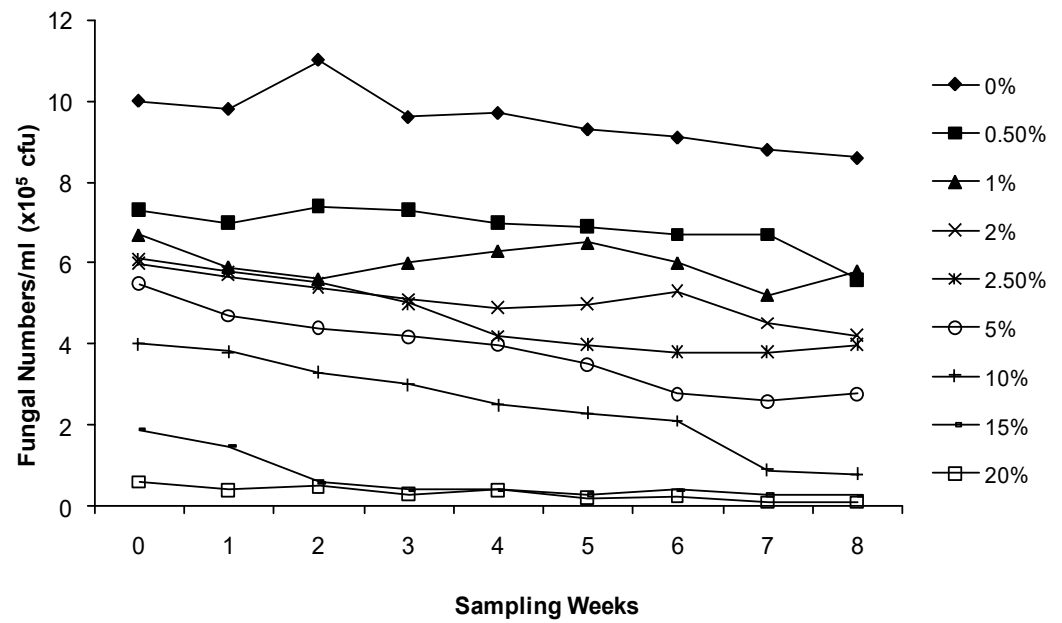

Figure 6 Effects of crude oil on the total colony count of fresh water fungi 


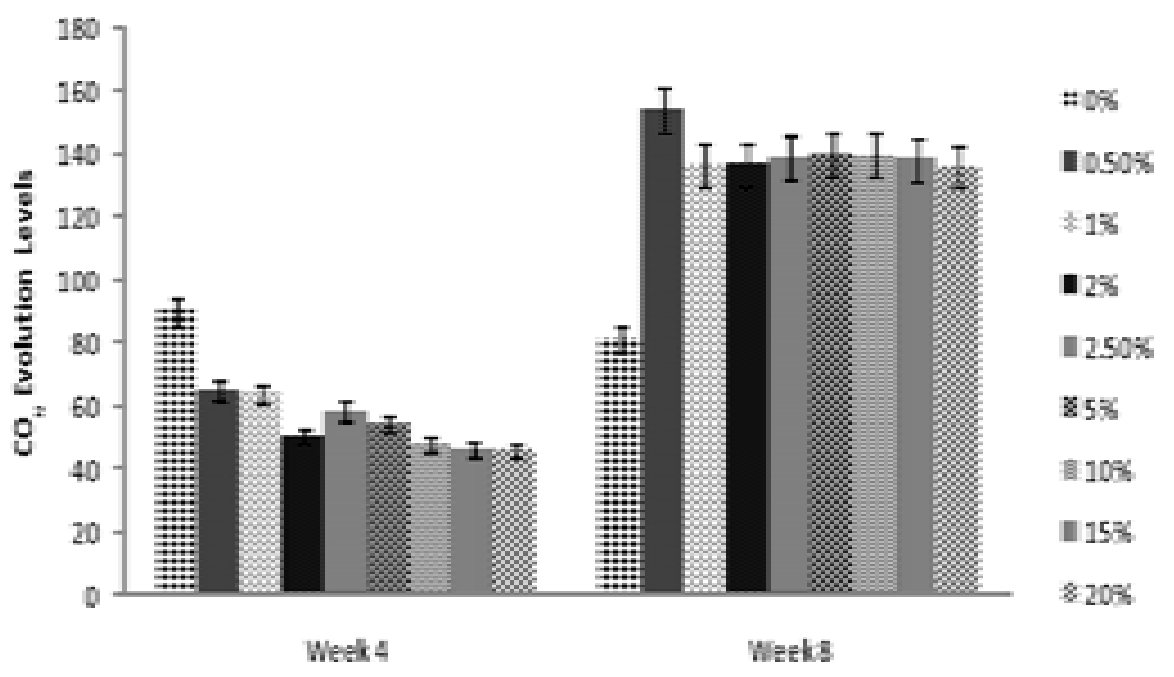

Weels

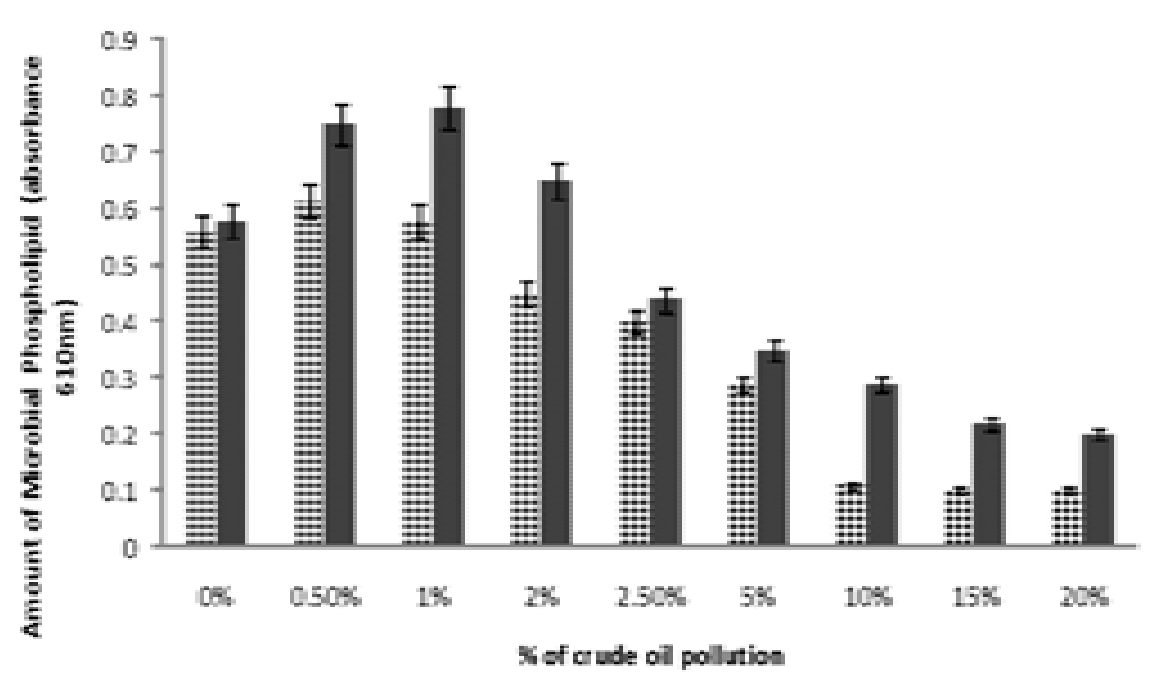

Figure 8 Effects of varying levels of crude oil on soil microbial phospholipids ( $\mathrm{nm} / \mathrm{g}$ of soil)

Journal of Experimental Biology and Agricultural Sciences http://www.jebas.org 


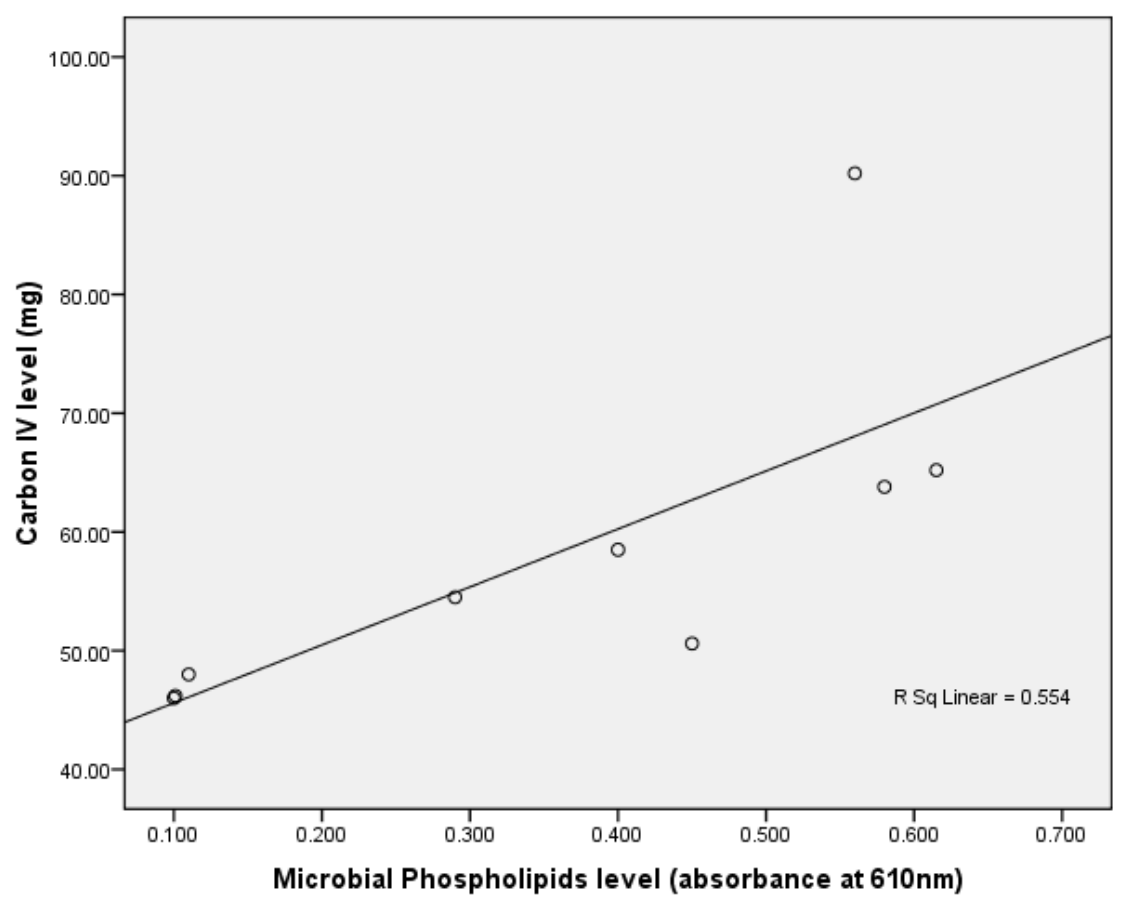

Figure 9 Relationship between microbial phospholipid and carbon (IV) oxide evolution from crude oil-contaminated soil samples.

The sharp decline observed in soil bacterial numbers from the first week up to the fourth week and subsequent gradual rise in population from the fifth to the eighth week might be the result of a decrease in the non-hydrocarbonoclastic bacterial population caused by the oil pollutant (Ebueli et al. 2005). The heterotrophic microorganisms (non-hydrocarbonoclastic) usually outnumber hydrocarbon degraders in unpolluted habitats and any introduction of a hydrocarbon pollutant will seriously reduce their numbers. On the contrary, the degradation facilities of hydrocarbonoclastic microorganisms are activated in the presence of hydrocarbon contaminants leading to utilization of the substrate and an increase in their population (Aniruddha \& Hermen 2010; Das \& Chandran, 2011; Owabor et al. 2011).

Both the aquatic and soil microorganisms had similar sensitivity patterns to crude oil toxicity. In general, the water bacteria demonstrated higher adaptive capacity to the oil than water fungi. This might be because of important role of bacteria in crude oil biodegradation than fungi. Further bacteria are more flexible as a result of the presence of more adaptation features. Furthermore, marine microorganisms more resisted to crude oil toxicity than their freshwater counterparts. This might be result of innate traits of the organisms (Chen et al., 2017) or the development of adaptive characteristics occasioned by pre-exposure of marine organisms to petroleum pollutants (Amanchukwu et al. 1989). These factors plays a significant role in pre-adaptation of marine organisms to hydrocarbons because of oil spills on the high seas caused by oil tanker accidents, oil leakages from motorized seafaring vessels and other offshore incidents that introduce petroleum into the sea.

The crude oil also had dose-dependent effects on soil microbial respiration and phosphoslipids content. Crude oil at high concentrations significantly $(\mathrm{P}<0.05)$ decreased the amounts of $\mathrm{CO}_{2}$ and PLP in the soil samples. This is because of its lethal effects on microbial cells. Phospholipids are a constituent of all cell membranes and their levels are always proportional to the bacterial biomass and they disappear soon after the death of the cell (Peterson et al. 1991). Therefore it follows that whatever affects microbial cell number will invariably affect the phospholipid phosphate level. According to Frostegard et al. (1991), phospholipid levels are used to measure total microbial biomass, activity and metabolic status.

\section{Conclusion}

The toxic effects of crude oil on microorganisms generally are more perceptible at high levels of the oil. On the other hand very low levels of crude oil enhance the growth of some groups of microorganisms. Additionally, marine microorganisms exhibit a higher tolerance to crude oil than their freshwater counterparts. More research work is needed to unravel and fully elucidate the 
reasons for the discrepancy between the reactions of marine and freshwater microorganisms to crude oil pollution.

\section{Acknowledgement}

The authors wish to acknowledge the support given by the Department of Microbiology, University of Nigeria, Nsukka through the provision of laboratory space and other facilities used for the work.

\section{Conflict of Interest}

Authors would hereby like to declare that there is no conflict of interests that could possibly arise.

\section{References}

Abdullah MA, Peramaiyan R (2019) Petroleum hydrocarbon and living organisms. In: Muharrem I, Olcay KI (Eds.), Hydrocarbon Pollution and Effects on the Environment. IntechOpen. Doi:10.5772/intechopen.86948.

Adedokun OM, Ataga AE (2007) Effects of amendments and bioaugmentation of soil polluted with crude oil, automotive gasoline oil and spent engine oil on the growth of cowpea(Vigna unguiculata). Scientific Research and Essays 2: 147-149.

Amanchukwu SC, Obafemi A, Okpokwasili GC (1989) Hydrocarbon degradation and utilization by a palm wine yeast isolate. FEMS Microbiology Letters 57: 151-154.

Aniruddha S, Hermen S (2010) Enhanced biodegradation of oil products by some microbl isolates supplemented with heavy metals. International Journal of Botany 6: 441-448.

Boethling RS, Alexander M (1979) Effect of concentration of organic chemicals on their biodegradation by natural microbial communities. Applied and Environmental Microbiology 37: 12111216.

Chen W, Li J, Sun X, Min J, Hu X (2017) High efficiency degradation of alkanes and crude oil by salt-tolerant bacterium Dietzia species CN-3. International Biodeterioration and Biodegradation 118: 110-118. Doi: 10.1016/j.ibiod.2017.01.029.

Das N, Chandran P (2011) Microbial degradation of petroleum hydrocarbon contaminants. Biotechnological Research International 2011. Article ID 941810, 13 Pages. http://dx.doi.org/10.4061/2011/941810.

Ebuehi OAT, Abibo IB, Shekwolo PD, Sigismund KI, Adoki A, Okoro IC (2005) Remediation of crude oil contaminated soil by enhanced natural attenuation technique. Journal of Applied Science and Environmental Management 9: 103-106.
Ekpo MA, Udofia US (2008) Rate of biodegradation of crude oil by microorganisms isolated from sludge environment. African Journal of Biotechnology 3: 4495-4499.

Eze CN, Maduka JN, Ogbonna JC, Eze EA (2013) Effects of Bonny light crude oil contamination on the germination, shoot growth and rhizobacterial flora of Vigna unguiculata and Arachis hypogea grown in sandy loam soil. Scientific Research and Essays 8: 99-107.

Findlay RH, King GM, Watling L (1989) Efficacy of phospholipids analysis in determining microbial biomass in sediments. Applied Environmental Microbiology 55: 2888-2893.

Frostegard A, Tunlid A, Bath E (1991) Microbial biomass measured as total lipid phosphate in soils of different organic content. Journal of Microbiological Methods 13 : 151-163.

Isermeyer H (1952) Eine eifache Methode zur Bestimmung der Bodenatmung und dem Karbonate im Boden. Zeitschrift für Pflanzenernährung und Bodenkunde 56 : 26-38.

Long SC, Aelion CM, Dobbins DC, Ptaender FK (1995) A comparison of microbial community characteristics among petroleum-contaminated and uncontaminated sub-surface soil samples. Journal of Microbial Ecology 30: 297-307.

Ma YL, Lu W, Wan LL, Luo L (2015) Elucidation of fluoranthene degradative characteristics in a newly isolated Achromobacter xylosoxidans DN OO2. Applied Biochemistry and Biotechnology 175: 1294-1305. Doi:10.1007/s12010-014-1347-7

National Oceanic and Atmospheric Administration (1992) Oil Spill Case Histories, 1967-1991: Summaries of Significant US and International spills. NOAA Report NO HMRAD 92-111.

National Research Council (2002) Oil in the sea 111: Inputs, Fates and Effects. Washington D C: National Academy Press.

Owabor CN, Onwuemene OC, Enaburekhan I (2011) Bioremediation of polycyclic aromatic hydrocarbon contaminated aqueous soil matrix: Effect of co-contamination. Journal of Applied Science and Environmental Management 15: 583-588.

Petersen SO, Henriksen K, Blackburu TH, King GM (1991) A comparison of phospholipids and chloroform fumigation analyses for biomass in soil, potentials and limitations. FEMS Microbial Ecology 85: 257-268.

Pezeshki SR, Hester MW, Lin Q, Nyman JA (2000) The effects of oil spill and clean-up on dominant US Gulf coast marsh macrophytes: A review. Environmental Pollution 108: 129-139. 
Wistreich GA (1997) Microbiology Laboratory: Fundamentals and Applications. Prentice-Hall Inc. New Jersey, USA. Pp. 144-186, 194-259.

Wang Y, Liang J, Wang J, Gao S (2018) Combining stable carbon isotope analysis and petroleum fingerprinting to evaluate petroleum contamination in the Yanchang oilfield located on loess plateau in China. Environmental Science and Pollution Research 25: 2830-2841.

Xingjian X, Wenming L, Shuhua T, Wei W, Qige Q, Pan J, Xinmei G, Fengjiao, Haiyan L, Hongwen Y (2018). Petroleum hydrocarbondegrading bacteria for the remediation of oil pollution under aerobic conditions : A perspective analysis. Frontiers in Microbiology 03 December 2018|https://doi.org/10.3389/fmicb.2018.02885.
Xinxin L, Ville AO, Kari S, Aki S (2019) Meat and bone meal as a novel biostimulation agent in hydrocarbon contaminated soils. Chemosphere 225: 574-578: Doi:10.1016/j.chemosphere.2019.03.053.

Xue J, Yu Y, Bai Y, Wang L,Wu Y (2015) Marine oil-degrading microorganisms and biodegradation process of petroleum hydrocarbon in marine environments: a review. Current Microbiology $71: 220-228$.

Yan S, Anna-Lea R, Martin R, Aki S (2018) Requirement of ecological replication with independent parallel analysis of each replicate plot to support soil remediation. International Biodeterioration and Biodegradation 133: 133-141. Doi:10.1016/j.ibiod.2018.06.006. 